\title{
Pengaruh Pertumbuhan Kredit Terhadap Profitabilitas dengan Tingkat Kolektibilitas Kredit Sebagai Pemoderasi Pada Lembaga Perkreditan Desa
}

\author{
Putu Utami Hariputri ${ }^{1}$ \\ Ida Bagus Dharmadiaksa ${ }^{2}$
}

\author{
${ }^{1}$ Fakultas Ekonomi dan Bisnis Universitas Udayana (Unud), Bali, Indonesia \\ email: putriutik92@yahoo.com/Telp: +6285 737585964 \\ ${ }^{2}$ Fakultas Ekonomi dan Bisnis Universitas Udayana (Unud), Bali, Indonesia
}

\begin{abstract}
ABSTRAK
Penelitian ini merupakan studi empiris yang bertujuan untuk mengetahui dan menguji pengaruh pertumbuhan kredit terhadap profitabilitas dan tingkat kolektabilitas kredit pada LPD. Penelitian ini dilakukan pada LPD yang terdapat di Denpasar pada periode tahun 2014-2016 dengan jumlah populasi sebanyak 35 LPD. Teknik pengambilan sampel yang digunakan penelitian ini adalah purposive sampling dengan kriteria. Penelitian ini menggunakan 105 sampel dan teknik analisis yaitu uji Moderated Regression Analysis dengan uji asumsi klasik yaitu uji normalitas, uji heterokedastisitas, dan uji autokorelasi. Berdasarkan hasil penelitian uji asumsi klasik menunjukan model regresi yang digunakan sudah tepat. Hasil penelitian menggunakan analisis regresi moderasi menunjukan pertumbuhan kredit berpengaruh siginifan terhadap profitabilitas. Hasilnya menunjukan bahwa meningkatnya pertumbuhan kredit diikuti dengan meningkatnya profitabilitas. Tingkat kolektibilitas kredit mampu memoderasi dengan memperlemah pengaruh negatif pertumbuhan kredit terhadap profitabilitas
\end{abstract}

Kata kunci: Profitabilitas, pertumbuhan kredit, tingkat kolektabilitas kredit

\begin{abstract}
This research is an empirical study which aims to know and test the effect of credit growth on profitability and credit collectability level in LPD. This research was conducted at LPD located in Denpasar in the period of 2014-2016 with total population of 35 LPD. The sampling technique used in this research is purposive sampling with criteria. This research uses 105 samples and analysis technique that is test of Moderated Regression Analysis with classical assumption test that is normality test, heterokedastisitas test, and autocorrelation test. Based on the results of the classical assumption test showed that the regression model used is correct. The result of research using moderation regression analysis showed that credit growth has a significant effect on profitability. The results show that increased credit growth is followed by increased profitability. The level of loan collectibility can moderate by weakening the negative effect of credit growth on profitability.

Keywords: Profitability, credit growth, collectability rate of credit.
\end{abstract}

\section{PENDAHULUAN}

Sebagian besar rakyat Indonesia berada di pedesaan, karena itu pembangunan ekonomi pedesaan adalah sangat penting dilakukan untuk menunjang perekonomian 
dan pembangunan nasional. Dengan adanya program pembangunan pedesaan maka pertumbuhan ekonomi pedesaan akan dapat mengangkat pertumbuhan ekonomi nasional. Pertumbuhan ekonomi sangat ditentukan oleh peningkatan di sektor keuangan (Abrams et al, 1999). Bali mempunyai suatu lembaga keuangan yang berfungsi dan berperan menggerakkan roda perekonomian di pedesaan yaitu Lembaga Perkreditan Desa yang biasa disingkat dengan LPD (Pradnyani, 2011). Lembaga Perkreditan Desa (LPD) merupakan sebuah badan usaha yang dimiliki oleh desa adat atau desa pakraman yang bergerak dibidang simpan pinjam. Desa adat atau desa pakraman merupakan kesatuan masyarakat hukum adat bersifat kemasyrakatan dan keagamaan.

Untuk mendukung keberadaan Lembaga Perkreditan Desa di Bali, maka sebagai payung hukumnya pemerintah Provinsi Bali mengeluarkan Peraturan Daerah (Perda) No. 2 tahun 1988 yang kemudian diganti dengan Perda No.8 tahun 2002. Karena kebutuhan untuk mengikuti perkembangan keadaan pada tahun 2012 pemerintah provinsi Bali mengeluarkan Perda No.4 tahun 2012 sebagai payung hukum mutakhir bagi keberadaan Lembaga Perkreditan Desa. Walaupun peraturannya berubah namun esensi LPD tetap tidak berubah. LPD tetap merupakan lembaga keuangan mikro yang pemiliknya adalah komunitas adat dengan sistem ekonomi bebanjaran khas Bali (Suartana, 2013).

Menjalankan kegiatannya LPD diawasi dan dibina oleh Bank Pembangunan Daerah Bali. Pengawasan dan pembinaan ini dilakukan untuk menjaga tingkat kesehatan LPD sehingga kelangsungan kegiatan operasionalnya tidak mendapat 
ISSN: 2302-8556

E-Jurnal Akuntansi Universitas Udayana

Vol.24.1.Juli (2018): 399-421

hambatan. BPD Bali No. 0193.02.10.2007.2 metode penelitian kesehatan LPD yang dipakai adalah metode CAEL (Capital, Asset, Earning, Liquidity). Salah satu unusr yang dinilai dalam CAEL adalah rentabilitas yang terdiri darim kinerja operasional dan profitabilitas.Unsur penilaian kesehatan LPD berdasarkan SK BPD Bali No. 0193.02.10.2007.2 adalah seperti Tabel berikut.

\section{Tabel 1.}

\section{Penilaian Kesehatan LPD}

\begin{tabular}{|c|c|c|}
\hline $\begin{array}{c}\text { Faktor yang } \\
\text { Dinilai }\end{array}$ & Komponen & Bobot \\
\hline 1. Permodalan & Rasio modal terhadap aktiva tertimbang menurut risiko (ATMR) & $30 \%$ \\
\hline $\begin{array}{l}\text { 2. Kualitas } \\
\text { Aktiva }\end{array}$ & $\begin{array}{l}\text { 1. Rasio aktiva yang diklasifikasikan terhadap aktiva } \\
\text { produktif }\end{array}$ & $30 \%$ \\
\hline Produktif & $\begin{array}{l}\text { 2. Rasio penyisihan penghapusan aktiva produktif yang } \\
\text { dibentuk LPD terhadap penyisihan wajib }\end{array}$ & $10 \%$ \\
\hline 3. Manajemen & $\begin{array}{l}\text { 1. Manajemen umum } \\
\text { 2. Manajemen risiko }\end{array}$ & $\begin{array}{l}0 \% \\
0 \%\end{array}$ \\
\hline 4. Rentabilitas & $\begin{array}{l}\text { 1. Rasio laba terhadap total aset } \\
\text { 2. Rasio biaya operasional terhadap pendapatan operasional }\end{array}$ & $\begin{array}{l}10 \% \\
10 \%\end{array}$ \\
\hline 5. Likuiditas & $\begin{array}{l}\text { 1. Rasio alat likuid terhadap hutang lancar } \\
\text { 2. Rasio kredit terhadap dana yang terima }\end{array}$ & $\begin{array}{l}5 \% \\
5 \%\end{array}$ \\
\hline
\end{tabular}

Sumber: SK BPD Bali tahun 2007

Berdasarkan Table 1 menjelaskan, dalam mengetahui kinerja keuangan LPD dapat menggunakan analisis CAEL untuk menunjukan kemampuan dalam menggunakan aktiva produktif dan dapat mengatur jalannya usaha secara efektif. Salah satu penilaian kesehatan dari LPD adalah rentalibilitas. Rentabilitas bank ini dapat terdiri dari profitabilitas dan kinerja operasional. 
Lembaga Perkreditan Desa juga mempunyai tujuan dalam memperoleh laba, walaupun itu tidak menjadi tujuan utama bagi LPD namun dalam melakukan kegiatannya harus juga memeperhatikan keuntungan yang didapat dari usahanya agar kelangsungannya dapat terjaga. Salah satu indikator penilaian kesehatan dari LPD adalah profitabilitas. Kemampuan perusahaan menghasilkan Laba dalam satu periode atau seitan periode tertentu disebut dengan profitabilitas. Rasio profitabilitas dapat digunakan untuk mengukur seberapa besar kemampuan perusaahan dalam memperoleh laba, baik hubungannya dengan penjualan asset, maupun laba bagi modal sendiri.

Dalam penelitian ini profitabilitas diproksikan dengan Return on Asset (ROA). Rasio ROA dapat dipengaruhi oleh faktor aktiva produktif yang salah satumya yaitu kredit (penjualan) yang diberikan, yang berkaitan dengan pendapatan dari LPD. Menurut Van Horne dkk, (2009:222) keuntungan bank dapat diukur dengan menggunakan analisis rasio keuangan yaitu profitabilitas, tepatnya dengan menggunakan ROA. ROA sangat penting bagi bank karena mampu mengukur efektifitas perusahaan di dalam menghasilkan keuntungan dengan pemanfaatan aktiva yang dimiliki. Semakin besar ROA mampu menjadikan bank menjadi lebih baik, karena tingkat pengembaliannya tinggi.

Kesuksesan dalam menyalurkan kredit ke masyarakat merupakan salah satu ukuran perkembangan sebuah LPD. Menurut Hasibuan (2004:100) pertumbuhan kredit merupakan gambaran tingkat perkembangan kredit yang disalurkan kepada pihak ketiga yang mampu memberikan peningkatan profitabilitas suatu lembaga 
ISSN: 2302-8556

keuangan dan meningkatkan kinerja lembaga keuangan. Pertumbuhan kredit menggambarkan tingkat perkembangan volume kredit yang disalurkan kepada pihak ketiga dalam periode tertentu (Saputra, 2014). Salah satu cara untuk menghitung tingkat kredit yang disalurkan adalah dengan menghitung Growth Rate. Dimana pertumbuhan kredit ini dihitung dari selisih jumlah kredit yang diberikan pada periode saat ini dengan jumlah kredit yang diberikan periode sebelumnya dibandingkan dengan jumlah kredit yang diberikan periode sebelumnya yang dinyatakan kedalam persentase (\%) (Sastrawan, 2014)

Tinggi rendahnya penghasilan LPD sangat ditentukan oleh kualitas dari kredit. Kualitas kredit ini berkaitan dengan tingkat kolektibilitas. Kolektibilitas ini merupakan penggolongan kredit berdasarkan kategori tertentu guna memantau kelancaran pembayaran kembali (angsuran) oleh debitur. Adriani (2013), kolektabilitas ini digunakan untuk mengukur kredit bermasalah yang mengalami kesulitan untuk pelunasan diluar kendali dari debitur. kredit bermasalah juga sering disebut dengan non performing loan (NPL). Semakin tinggi nilai NPL, maka akan semakin buruk kualitas suatu kredit yang menyebabkan jumlah kredit bermasalah semakin besar sehingga pihak penyalur kredit harus menanggung kerugian dalam kegiatan operasionalnya sehingga berpengaruh terhadap penurunan laba yang akan diperoleh kreditur (Fifit, 2013).

Berdasarkan dari hasil penelitian Prawira (2011) dan Rastyniyanti (2015) memberikan hasil bahwa secara parsial pertumbuhan kredit berpengaruh signifikan terhadap profitabilitas, sedangkan hasil menurut Anggraeini (2010) dan Rusydi 
(2007) tidak menunjukan pengaruh signifikan pertumbuhan kredit terhadap profitabilitas. Dalam penelitian ini digunakan variabel moderasi, dimana variabel pemoderasi yang digunakan adalah tingkat kolektibilitas kredit. Penggunaan tingkat kolektibilitas ini agar dapat mengantisipasi risiko kredit yang dapat mempengaruhi kelangsungan usaha. Tingkat kolektabilitas ini juga dapat digunakan untuk menetapkan tingkat cadangan potensi kerugian akibat dari kredit yang bermasalah.

Demikian melihat pentingnya arti LPD bagi masyarat Bali, maka dilakukan penelitian di LPD-LPD yang berada di Kota Madya Denpasar dengan judul “Pengaruh Pertumbuhan Kredit terhadap Profitabilitas dengan Tingkat Kolektibilitas Kredit sebagai Pemoderasi pada Lembaga Perkreditan Desa Denpasar”

LPD merupakan salah salah satu lembaga keuangan milik desa pakraman, yang menjalankan salah satu fungsi keungan yang dimiliki desa pakraman yaitu usaha simpan pinjam masyarakat desa pakraman yang berada di Provinsi Bali dan merupakan sarana perekonomian rakyat di desa.

Menurut Peraturan Daerah Provinsi Bali Nomor 3 Tahun 2007, LPD merupakan badan usaha keungan milik desa yang melaksanakan kegiatan usaha di lingkungan desa dan untuk krama desa. Menurut keputusan Gubernur Bali Nomor 3 Tahun 2003, LPD merupakan Lembaga Perkreditan Desa di desa prakaman dalam wilayah Provinsi Bali. LPD merupakan salah satu aset atau sumber pendapatan desa adat sehingga memerlukan pengelolaan yang baik oleh pengurus LPD untuk 
ISSN: 2302-8556

menjangkau seluruh kegiatan masyarakat desa terutama dalam menjalankan usahanya (Darsana, 2010).

Fungsi dari LPD menurut Perda Tingkat I Bali Nomor 2 Tahun 1988 menyebutkan dalam pasal 3 bahwa : 1). LPD adalah salah satu lembaga desa yang merupakan unit operasional serta berfungsi sebagai wadah kekayaan desa berupa uang atau surat-surat berharga; 2). Pendayagunaan LPD diarahkan kepada usahausaha peningkatan taraf hidup krama desa untuk menunjang pembangunan.

Tujuan didirikannya LPD sesuai dengan Perda Tingkat I Nomor 2 tahun 1988 menyebutkan bahwa: 1). Mendorong pembangunan ekonomi masyarakat desa melalui tabungan yang terarah serta menyalurkan modal yang efektif; 2). Memberantas ijon, gadai gelap dan sejenisnya; 3). Menciptakn pemerataan dan kesempatan berusaha bagi warga desa dan tenaga kerja di pedesaan; 4). Meningkatkan daya beli dan kelancaran lalu lintas pembayaran dan peredaran uang. Dalam sejarah perkembangan Lembaga Perkreditan Desa ada beberapa peraturan yang dikeluarkan oleh Gubernur dan Peraturan Daerah yang menjadi dasar dalam pembentukan Lembaga Perkreditan Desa yaitu;

Keputusan Kepala Daerah Tingkat I Bali Nomor 972 Tahun 1984 yang mengatur tentang posisi dan fungsi LPD sebagai unit operasional dan wadah kekayaan desa prakaman baik dalam bentuk uang maupun surat berharga lainnya. Peraturan Daerah Nomor 8 tahun 2002 yang mengatur tentang LPD, yang diperkuat dengan 5 peraturan kebijakan, yaitu: 1). Keputusan Gubernur Nomor 3 Tahun 2003 tentang status dan tugas-tugas pembinaan Lembaga Perkreditan Desa 
Kabupaten/Kota; 2). Keputusan Gubernur Nomor 4 Tahun 2003 tentang penyetoran dan penggunaan keuntungan bersih LPD; 3). Keputusan Gubernur Nomor 7 Tahun 2003 tentang dana perlindungan LPD; 4). Keputusann Gubernur Nomor 8 Tahun 2003 tentang pembentukan badan pembina LPD di Provinsi Bali; 5). Keputusan Gubernur Nomor 12 Tahun 2003 tentang pronsip kehati-hatian dalam pengelolaan LPD.

Peraturan Daerah Nomor 3 tahub 2007 tentang perubahan atas peraturan daerah provinsi Bali Nomor 8 Tahun 2002 tentang LPD yang dijabarkan kedalam 1 peraturan Gubernur dan 2 keputusan Gubernur, yaitu; 1). Peraturan Gubernur Nomor 16 Tahun 2008 tentang pengurus dan pengawas internal LPD; 2). Keputusan Gubernur Bali Nomor 11/01-C/HK/2008 tentang pembentukan badan pembina umum LPD Provinsi Bali; 3). Keputusan Gubernur Bali Nomor 1499/01-C/HK/2008 tentang status dan tugas-tugas pembina LPD (PLPDP) Bali dan PLPDK.

Peraturan Daerah Nomor 4 Thun 2012 tentang perubahan kedua atas Peraturan Daerah Provinsi Bali Nomor 8 Tahun 2002 tentang LPD yang dijabarkan kedalam keputusan Gubernur, yaitu: 1). Keputusan Gubernur Bali Nomor 4 Tahun 2003 tentang penyetoran dan penggunaan keuntungan bersih LPD; 2). Keputusan Gubernur Bali Nomor 95/01-C/HK/2003 tentang pelimpahan wewenang pengawasan LPD di Provinsi Bali kepada BPD Bali; 3). Keputusan Gubernur Bali Nomor 7 Tahun 2003 tentang dana perlindungan LPD; 4). Keputusan Gubernur Bali Nomor 1499/01C/HK/2008 tentang status dan tugas-tugas PLPDP dan PLPDK; 5). Keputusan Gubernur Bali Nomor 12 Tahun 2003 tentang prinsip kehati-hatian pengelola LPD; 
6). Peraturan Gubernur Bali Nomor 17 Tahun 2006 tentang pembentukan LPP LPD; 7). Keputusan Gubernur Bali Nomor 450/2006 tentang pembentukan dan susunan keanggotaan LPP LPD; 8). Keputusan Gubernur Bali Nomor 16 Tahun 2008 tentang pengurus dan pengawasan internal LPD, dicabut dan dinyatakan tidak berlaku.

Sebagai produk jasa utama, LPD harus meningkatkan produktivitasnya agar mampu menghasilkan laba atau profit dalam meningkatkan pelayanan jasa kredit. Dengan kemudahan yang diberikan oleh LPD dalam tingginya penyaluran kredit pada masyarakat untuk investasi maka dapat membantu meningkatkan usaha skala kecil di pedesaan. Permintaan kredit konsumsi dan investasi akan tetap atau meningkatkan menunjukan bahwa perolehan atau pendapatan dari bunga kredit akan semakin besar dan meningkatkan profitabilitas (Daryanti dan Idah, 2010). Profitabilitas merupakan kemampuan suatu perusahaan untuk mendapatkan laba dalam periode tertentu dalam hubungannya dengan penjualan, total aktiva, maupun modal sendiri. Definisi profitabilitas menurut Brigham dan Houston (2009:17) adalah jumlah akhir dari jumlah kebijakan dan keputusan yang dilakukan oleh perusahaan dengan sekelompok rasio yang menunjukan efek-efek dari likuiditas, manajemen aktiva dan utang pada hasil-hasil operasi.

Profitabilitas adalah rasio yang membandingkan laba dengan penjualan dan investasi (Tarigan dan Hasan, 2009). Profitabilitas juga mempunyai arti penting dalam usaha mempertahankan kelangsungan hidup suatu perusahaan dalam jangka panjang. Menurut R. Agus Sartono (2010:122), profitabilitas adalah kemampuan 
perusahaan memperoleh laba dalam hubungannya dengan penjualan, total aktive maupun modal sendiri. Hubungan profitabilitas dengan siklus bisnis sektor perbankan sangat penting untuk menilai tingkat kesehatan dan kemantapan suatu lembaga perbankan (Agus Ardiana, 2012). Keuntungan merupakan syarat mutlak dari lembaga perbankan dan secar luas, lembaga keuangan yang menguntungkan akan mampu membuat sistem perekonomian suatu negara mejadi kuat dan berkembang (Khizer Ali dkk, 2011) Sedangkan pendapat lainnya tentang profitabilitas merupakan kemampuan suatu bank untuk memperileh laba yang dinyatakan dalam persentase, profitabilitas pada dasarnya adalah laba yang dinyatakan dalam persentase profit (Raharjo dan Linda, 2005). Dapat disimpulkan pengertian dari profitabilitas merupakan kemampuan suatu perusahaan yang menghasilkan suatu keuntungan selama periode tertentu dengan modal yang digunakan.

Profitabilitas sebagai variabel independen dalam penelitian ini diproksikan denga ROA. Dendawijaya (2000) mengatakan profitabilitas merupakan kemampuan bank untuk menghasilkan atau memperoleh laba yang diukur dengan rasio ROA. Menurut Munawir (2002:269), Return on Assets menggambarkan kemampuan perusahaan untuk memperoleh hasil atas sumber daya keuangan yang ditanamkan oleh perusahaan. Return on Assets menurut Hanafi dan Halim (2003:27) adalah rasio keuangan perusahaan yang terkait dengan potensi keuntungan mengukur kekuatan perusahaan membuah keuntungan atau juga laba pada tingkat pendapatan, aset dan juga modal saham spesifik. 
Kredit adalah penyedia uang atau tagihan yang dapat disamakan dengan itu, berdasarkan persetujuan atau kesepakatan pinjam meminjam antara bank dan pihak lain yang mewajibkan pihak peminjam untuk melunasi utangnya setelah jangka waktu tertentu dengan pemberian bunga. Kredit dapat berfungsi untuk membantu masyarakat dalam memenuhi kebutuhannya melalui penyaluran dana yang diberikan oleh bank. Pinjaman atau kredit yang dikeluarkan oleh bank kepada masyarakat merupakan salah satu bentuk penggunaan dana bank yang paling besar dalam usaha pendapatan penghasilan. Hasil dana tersebut dapat berupa bunga kredit (Sudirman, 2000:32).

Pertumbuhan kredit dapat diartikan menjadi jumlah dari pertumbuhan aktiva produktif yang dalam hal ini adalah kredit, yang merupakan penyerahan barang, jasa, atau uang dari pihak satu ke pihak yang lain atas dasar kepercayaan denag janji membayar pada tanggal yang telah disepakati bersama (Hakim, 2009). Pertumbuhan kredit merupakan pertumbuhan dari penyediaan uang atau tagihan yang dapat dipersamakan dengan itu, berdasarkan persetujuan atau kesepakatan pinjam meminjam antar bank dengan pihak lain, yang mewajibkan pihak lain untuk melunasi utangnya setelah jangka waktu tertentu pemberian uang.

Pertumbuhan kredit ini dapat dihitung atau diukur dari selisih antara jumlah kredit yang diberikan pada pereiode ini dengan jumlah kredit yang diberikan pada periode sebelumnya dibandingkan dengan jumlah kredit yang diberikan pada periode sebelumnya yang dinyatakan kedalam persentase (\%). Jika jumlah kredit semakin baik dan berkesinambungan maka dapat memberikan kesempatan bagi masyarakat 
untuk mengakses dana serta mampu meningkatkan pertumbuhan pendapatan (Mukkaromah, 2014). Kolektibiliitas kredit merupakan penggolongan kredit dengan membagi atau memisah-misahkan kredit/pinjaman berdasarkan kelancaran atau ketidaklancaran pengembalian kredit atau pinjaman tersebut baik pokok ataupun bunganya.Hal ini ditujukan untuk mengetahui dan mendapat gambaran yang nyata tentang keadaan dan kondisi kredit kredit/pinjaman yang telah diberikan kepada masyarakat sebagai pemakai dana sekaligus untuk melihat keseriusan kreditur dalam menangani kreditnya

Penetapan kualitas kredit mengacu pada ketentuan Bank Indonesia, yaitu PBI No.14/15/PBI/2012 tentang Penilaian Kualitas Aset Bank Umum dan SEBI No.7/3/DPN tanggal 31 Januari 2005 perihal Penilaian Kualitas Aktiva Bank Umum. Kelompok atau golongan dalam SEBI tersebut adalah sebagai berikut: 1). Lancar (Kolektibilitas 1), apabila tidak terdapat tunggakan pembayaran pokok dan/atau bunga; 2). Dalam Perhatian Khusus (Kolektibilitas 2), apabila terdapat tunggakan pembayaran pokok dan/atau bunga sampai dengan 90 hari; 3). Kurang Lancar (Kolektibilitas 3), apabila terdapat tunggakan pembayaran pokok dan/atau bunga sampai dengan 120 hari; 4). Diragukan (Kolektibilitas 4), apabila terdapat tunggakan pembayaran pokok dan atau bunga sampai dengan 180 hari; 5). Macet (kolektibiltas 5), apabila terdapat tunggakan pembayaran pokok dan/atau bunga di atas 180 hari.

Berdasarkan kelima golongan tersebut kredit dapat digolongkan menjadi dua yaitu kredit lancar yang disebut juga dengan performing loan dan kredit macet yang 
ISSN: 2302-8556

disebut juga dengan non performing loan (NPL). Tujuan klasifikasi tersebut, antara lain untuk menetapkan tingkat cadangan potensi kerugian akibat kredit bermasalah.

Sebagai produk jasa utama, LPD harus meningkatkan produktivitasnya agar mampu menghasilkan laba atau profit dalam meningkatkan pelayanan jasa kredit. Dengan kemudahan yang diberikan oleh LPD dalam tingginya penyaluran kredit pada masyarakat untuk investasi maka dapat membantu meningkatkan usaha skala kecil di pedesaan. Permintaan kredit konsumsi dan investasi akan tetap atau meningkatkan menunjukan bahwa perolehan atau pendapatan dari bunga kredit akan semakin besar dan meningkatkan profitabilitas (Daryanti dan Idah, 2010)

Pertumbuhan kredit menggambarkan tingkat perkembangan volume kredit yang disalurkan kepada pihak ketiga yang mampu memberikan peningkatan profitabilitas dan meningkatkan kinerja perbankan (Pradnyawati, 2012). Dengan tingginya kredit yang disalurkan pada masyarakat akan menunjukan semakin tinggi penjualan berupa kredit sehingga keuntungan atau laba dapat secara otomatis meningkat.

$\mathrm{H}_{1} \quad$ : Pertumbuhan kredit berpengaruh terhadap profitabilitas LPD

Pada penelitian ini tingkat kolektibilitas kredit bertujuan untuk mengetahui dan mendapat gambaran yang nyata tentang keadaan dan kondisi kredit kredit/pinjaman yang telah diberikan kepada masyarakat sebagai pemakai dana sekaligus untuk melihat keseriusan kreditur dalam menangani kreditnya. Hasil dari penelitian Prawira dan Wishada (2011) bahwa pertumbuhan kredit berpengaruh signifikan terhadap profitabilitas. Penelitian dari Nurdin dan Pasiangi (2010) menunjukan bahwa tingkat kolektibilitas kredit berpengaruh terhadap profitabilitas. Mardi dan Faradila (2016) 
mengatakan bahwa dengan adanya kredit bermasalah, bank akan kehilangan kesempatan untuk memperoleh pendapatan dari kredit yang diberikan, sehingga mengurangi perolehan laba dan berpengaruh buruk pada profitabilitas.

Dendawijaya (2000) menyatakan implikasi bagi pihak kreditur sebagai akibat timbulnya tersebut dapat menyebabkan hilangnya kesempatan untuk memperoleh pendapatan dari kredit yang diberikan, sehingga mengurangi perolehan laba dan membawa pengaruh buruk bagi rentabilitas dan return on assets (ROA) mengalami penurunan. Semakin menurunnya pendapatan bunga dari penyaluran kredit juga dapat menurunkan profitabilitas.

$\mathrm{H}_{2}$ : Tingkat kolektibilitas kredit mampu mempengaruhi hubungan antara pertumbuhan kredit terhadap profitabilitas LPD.

\section{METODE PENELITIAN}

Penelitian ini adalah penelitian asosiatif dimana penelitian yang bertujuan untuk mengetahui hubungan dari variabel atau lebih. Variabel yang digunakan dalam penelitian ini adalah Variabel Bebas terdiri dari Pertumbuhan Kredit, Variabel Pemoderasi, yaitu Tingkat Kolektibilitas Kredit, dan Variabel Terikat, yaitu Profitabilitas. Lokasi penelitian ini dilakukan pada LPD yang berada di Kota Madya Denpasar. Lokasi penelitian ini dilakukan pada Lembaga Pemberdayaan Lembaga Perkreditan Desa (LP LPD) Denpasar yang merupakan lembaga pemerintahan yang memberikan pembinaan dan pengawasan bagi LPD yang berada di kota/kabupaten di Bali. Pemilihan kota Denpasr untuk menjadi lokasi penelitian karena semakin berkembangnya kota Denpasar, maka perkembangan LPD semakin pesat dalam 
ISSN: 2302-8556

membantu masyarakat sekitar untuk melakukan kegiatan menyimpan dan meminjam dana. Objek penelitian merupakan atribut atau sifat nilai dari orang atau kegiatan yang mempunyai variasi tertentu yang ditetapkan oleh peneliti untuk dipelajari dan ditarik kesimpulannya (Sugiyono, 2012:58). Objek dari penelitian ini adalah seluruh LPD di kota Denpasar yang terdaftar di LP LPD kota Denpasar pada periode 20142016 mengenai pertumbuhan kredit, tingkat perputaran kredit dan profitabilitas

Sampel yang digunakan dalam penelitian ini diambil dengan menggunakan Metode Sampel purposive sampling, yaitu metode penentuan sampel dengan pertimbangan tertentu, diman anggota sampel yang dipilih sedemikian rupa sehingga sampel yang terbentuk dapat mewakili sifat-sifat populasi (Sugiyono, 2012:122). Sampel untuk LPD di Kota Madya Denpasar memiliki syarat-syarat sebagai berikut: 1). LPD-LPD yang berada di Kota Madya Denpasar yang terdaftar di Lembaga Pemberdayaaan Lembaga Perkreditan Desa (LP LPD); 2). Tidak mengalami kerugian dan melaporkan laporan keuangannya selama periode 2014-2016. Dari kriteria diatas didapatkan total 105 Sampel Penelitian. Teknik analisis data yang digunakan pada penelitian ini adalah analisis Moderated Regression Analysis (MRA) dan pengolahannya dibantu dengan program Statistical Package for Social Science (SPSS). Sebelum melakukan model regresi untuk uji hipotesi, maka terlebih dahulu dilakukannya uji asumsi klasik.

\section{HASIL DAN PEMBAHASAN}

Statistik deskriptif disajikan untuk memberikan informasi mengenai karakteristik variabel-variabel penelitian, antara lain nilai maksimum, nilai minimum, mean dan 
standar deviasi. Asumsi yang digunakan dalam penelitian ini adalah Uji Normalitas, Uji Heterokedastisitas, dan Uji Autokorelasi. Adapun hasil analisis dari masingmasing tahapan pengujian.

\section{Statistik Deskriptif}

\begin{tabular}{lrrrrr}
\hline & N & Minimum & Maximum & \multicolumn{1}{l}{ Mean } & Std. Deviation \\
\hline Y & 102 &, 015479 &, 515871 &, 05117779 &, 048952957 \\
X1 & 102 &,- 880748 &, 655709 &, 17654181 &, 150869333 \\
X2 & 102 &, 000023 & 5,175700 &, 24809440 &, 786946326 \\
X1_X2 & 102 &,- 527025 & 1,419333 &, 05577364 &, 226267411 \\
Valid N (listwise) & 102 & & & & \\
\hline
\end{tabular}

Sumber: Data diolah, 2017

Tabel 2 menunjukkan bahwa nilai minimum variabel pertumbuhan kredit $\left(X_{1}\right)$ memiliki nilai minimum $-0,880748 \%$ yang diperoleh oleh LPD Pedungan, nilai maksimum sebesar 0,655709\% yang diperoleh oleh LPD Denpasar. Nilai rata-rata dari pertumbuhan kredit $\left(X_{1}\right)$ sebesar $0,17654181 \%$, artinya sebesar $0.17654181 \%$ LPD menyalurkan dananya pada masyarakat selama 1 tahun. Standar deviasi untuk variabel pertumbuhan kredit $\left(X_{1}\right)$ sebesar $0,150869333 \%$ menunjukan bahwa nilai standar deviasi lebih rendah dari nilai rata-rata, sehingga data variabel pertumbuhan kredit $\left(X_{1}\right)$ dikatakan baik.

Variabel tingkat kolektibilitas kredit $\left(X_{2}\right)$ memiliki nilai minimum sebesar 0,000023\% yang diperoleh oleh LPD Denpasar, nilai maksimum sebesar 5,175700\% yang diperoleh oleh LPD Lap-Lap. Nilai rata-rata dari tingkat kolektibilitas kredit sebesar 0,24809440\% itu artinya LPD berhasil memperkecil kredit yang bermasalah sebesar 0,24809440 kali selama 1 tahun. Standar deviasi untuk tingkat kolektibilitas 
kredit $\left(X_{2}\right)$ sebesar 0,786946326\% menunjukan bahwa lebih tnggi dari nilai rata-rata, sehingga tingkat variabel kolektabilitas kredit dapat dikatakan tidak baik.

Variabel profitabilitas (Y) memiliki nilai minimum sebesar 0,015479\% yang diperoleh oleh LPD Intaran, nilai maksimum sebesar 0,515871\% yang diperoleh oleh LPD Pedungan. Nilai rata-rata sebesar 0,05117779\%, artinya LPD mampu memperoleh laba sebesar 0,05117779\% selama 1 tahun. Standar deviasi untuk profitabilitas (Y) adalah 0,048952957\% menunjukan bahwa nilai standar deviasi lebih rendah daripada nilai rata-rata, sehingga variabel profitabilitas dapat dikatakan baik.

Tabel 3.

Uji Normalitas

\begin{tabular}{llr}
\hline & & $\begin{array}{c}\text { Unstandardized } \\
\text { Residual }\end{array}$ \\
\hline $\mathrm{N}$ & Mean & 102 \\
Normal Parameters $^{\mathrm{a}, \mathrm{b}}$ & Std. Deviation &, 0000000 \\
& Absolute &, 23492203 \\
Most Extreme Differences & Positive &, 069 \\
& Negative &, 048 \\
Test Statistic & &,- 069 \\
Asymp. Sig. (2-tailed) & &, 069 \\
Sumber: Data diolah, 2017 & &, $200^{\text {c,d }}$ \\
\hline
\end{tabular}

Berdasarkan tabel 3 diatas hasil yang diperoleh menggunakan uji KolmogorovSmirnov dengan signifikanlebih besar dari 0.05 yaitu 0.200 , maka dapat dikatakan data terdistribusi secara normal.

\section{Tabel 4.}

\section{Uji Autokorelasi}

\begin{tabular}{lrrrrr}
\hline Model & R & R Square & $\begin{array}{c}\text { Adjusted R } \\
\text { Square }\end{array}$ & $\begin{array}{c}\text { Std. Error of } \\
\text { the Estimate }\end{array}$ & Durbin-Watson \\
\hline 1 &, $845^{\mathrm{a}}$ &, 715 &, 706 &, 026551491 & 2,004 \\
\hline
\end{tabular}

Sumber: Data diolah, 2017 
Tabel 4 menunjukkan bahwa nilai DW sebesar 2.004, dengan level of signifikan $0.05, \mathrm{n}=35$ dan nilai $\mathrm{du}=1.65$ serta nilai $4-\mathrm{du}=2.35$. Berdasarkan hasil tersebut dapat disumpulkan penelitian ini todak mengandung gejala autokolerasi sehingga penelitian inilayak digunakan

Tabel 5.

Uji Heterokedastisitas

\begin{tabular}{|c|c|c|c|c|c|c|}
\hline \multirow{2}{*}{\multicolumn{2}{|c|}{ Model }} & \multicolumn{2}{|c|}{$\begin{array}{l}\text { Unstandardized } \\
\text { Coefficients }\end{array}$} & \multirow{2}{*}{$\begin{array}{l}\text { Standardized } \\
\text { Coefficients } \\
\text { Beta }\end{array}$} & \multirow[b]{2}{*}{$\mathbf{t}$} & \multirow[b]{2}{*}{ Sig. } \\
\hline & & B & Std. Error & & & \\
\hline \multirow[t]{4}{*}{1} & (Constant) & ,940 & ,220 & & 4,284 &, 000 \\
\hline & $\mathrm{X} 1$ &, 002 & ,084 & ,002 & ,024 & ,981 \\
\hline & $\mathrm{X} 2$ &,- 056 & 328 &,- 041 &,- 171 & ,864 \\
\hline & X1_X2 & ,003 & 297 & ,003 & ,010 & ,992 \\
\hline
\end{tabular}

Sumber: Data diolah, 2017

Berdasarkan Tabel 5 di atas, dapat disimpulkan bahwa semua variabel memiliki Asymp. Sig (p value) lebih besar daripada 0.05 , artinya pada model regresi tidak terdapat heterokedastisitas

\section{Tabel 6.}

Hasil Uji Moderated Regression Analysis

\begin{tabular}{llrrrrr}
\hline & \multicolumn{7}{c}{$\begin{array}{c}\text { Unstandardized } \\
\text { Coefficients }\end{array}$} & $\begin{array}{c}\text { Standardized } \\
\text { Coefficients } \\
\text { Model }\end{array}$ & \multicolumn{1}{c}{ Std. Error } & \multicolumn{1}{c}{ Beta } & \multicolumn{1}{c}{ Sig. } \\
\hline 1 & (Constant) &, 048 &, 006 & & 8,205 &, 000 \\
& X1 &,- 020 &, 027 &,- 060 &,- 721 &, 473 \\
& X2 &, 143 &, 014 & 2,305 & 9,889 &, 000 \\
& X1_X2 &,- 515 &, 054 & $-2,378$ & $-9,611$ &, 000 \\
\hline
\end{tabular}

Sumber: Data diolah, 2017

Hasil analisi regresi linear berganda pada Tabel 6 diatas dapat disimpulkan persamaan regresinya sebagai berikut.

$$
\mathrm{Y}=0,048-0,20 \mathrm{X} 1+0,143 \mathrm{X} 2-0,515 \mathrm{X} 1 \mathrm{X} 2+\varepsilon \mathrm{i}
$$

Arti dari koefisien regresi di atas adalah sebagai berikut. $\alpha=$ Nilai konstanta sebesar 0,048, artinya bila pertumbuhan kredit (X1), dan tingkat kolektibilitas kredit 
(X2) sama dengan nol, maka profitabilitas (Y) adalah sebesar $0,048 \% \cdot \beta_{1}=-0,20$, artinya bila pertumbuhan kredit (X1) bertambah 1\% maka profitabilitas (Y) akan mengalami penurunan sebesar $-0,201 \%$ dengan asumsi variabel yang lain konstan. $\beta_{2}$ $=0,143$, artinya bila tingkat kolektibilitas bertambah $1 \%$, maka profitabilitas (Y) akan mengalami penurunan $0,143 \%$, dengan asumsi variabel lain konstan. $\beta_{3}=-0.515$, artinya bila interaksi antara tingkat kolektibilitas (X2) dan pertumbuhan kredit (X1) mengalami kenaikan dengan asumsi variabel lainnya konstan, maka profitabilitas akan mengalami penurunan sebesar $-0.515 \%$

Hasil persamaan regresi linear berganda tersebut menunjukan arah pegaruh masing-masing variabel bebas dan terikat yang ditunjukan oleh masing-masing koefisien variabel bebasnya. Hasil analisis regresi linear berganda pada tabel 4.6 juga dapat dilihat nilai $R^{2}$ sebesar 0.715 , hal ini berarti $17,5 \%$ perubahan profitabilitas (Y) LPD di Kota Denpasar selama periode 2014-2016 dibengaruhi oleh varian variabel pertumbuhan kredit dan tingkat kolektabilitas kredit, sedangkan sisanya sebesar 82.5\% dipengaruhi variabel lain yang tidak dimasukan dalam penelitian. Berdasarkan Tabel 6 diketahui bahwa nilai variabel pertumbuhan kredit memiliki nilai koefisien negatif sebesar -0.020 dengan nilai signifikansinya sebesar 0.473 . nilai ini lebih besar dari $\alpha$ yaitu 0.05 , maka $H_{0}$ diterima $H_{1}$ ditolak sehingga pertumbuhan kredit berpengaruh terhadap profitabilitas LPD di Kota Denpasar perode 2014-2016

Berdasarkan Tabel 6 di atas variabel interaksi antara tingkat kolektabilitas kredit dan perputaran kredit memiliki koefisien negatif sebesar -0.515 dengan nilai 
signifikansinya sebesar 0,000 . Nilai ini lebih kecil dari $\alpha$ yaitu 0.05 , maka $H_{0}$ ditolak $H_{1}$ diterima sehingga pada penelitian ini bahwa kolektibilitas kredit mempengaruhi hubungan pertumbuhan kredit terhadap profitabilitas LPD di Kota Denpasar periode 2014-2016

\section{SIMPULAN}

Berdasarkan hasil penelitian yang diperoleh melalui pengujian statistik serta pembahasan yang telah diuraikan pada bab sebelumnya, maka dapat diambil kesimpulannya sebagai berikut: 1). Variabel tingkat pertumbuhan kredit berpengaruh signifikan terhadap profitabilitas Lembaga Perkreditan Desa (LPD) di Kota Denpasar periode 2014-2016. Hal ini dapat dikatakan LPD mampu menyalurkan kredit dengan cukup baik kepada masyarakat yang menyebabkan semakin banyak pendapat bunga yang diterima LPD sehinnga profitabilitas LPD semakin meningkat; 2). Variabel tingkat kolektabilitas kredit berpengaruh signifikan dalam mempengaruhi hubungan antara pertumbuhan kredit terhadap profitabilitas Lembaga Perkreditan Desa (LPD) di Kota Denpasar periode 2014-2016. Dengan meningkatnya pendapat bunga maka dapat diartikan jika LPD dapat memperkecil risiko kredit, LPD mampu menagih kredit-kredit yang temasuk kedalam kredit bermasalah.

Saran bagi peneliti selanjutnya adalah 1). Diharapkan dapat menggunakan variabel lain sebagai variabel pemoderasi seperti menggunakan komponen kesehatan LPD lainnya misalnya Capital, Asset, dan Earning; 2). Bagi peneliti berikutnya 
ISSN: 2302-8556

E-Jurnal Akuntansi Universitas Udayana

Vol.24.1.Juli (2018): 399-421

hendaknya meneliti pertumbuhan kredit dan tingkat kolektabilitas kredit terhadap profitabilitas pada lokasi penelitian dan periode yang berbeda.

\section{REFERENSI}

Abrams, Burton A., Margaret Z. Clarke dan Russell F. Settle. 1999. The Impact of Banking and Fiscal Policies on State-Level economic Growth. Southern Economic Journal, 66 (2), pp: 367-378.

Ardiana, Putu Agus dan Luh Kartika Eka Sari. 2012. "Pengaruh Variabel Aset Lancar, Debt to Total Assets, Umur dan Jumlah Anggota Terhadap Rentabilitas Ekonomi”. Jurnal Akuntansi dan Bisnis, 5 (2):h:126-138.

Brigham dan Houston, 2009. Fundamentals of Finacial Management, South-Western.

Darsana, Ida Bagus, 2010. Peranan dan Kedudukan Lembaga Perkreditan Desa (LPD) dalam Sistem Perbankan di Indonesia. Buletin Ekonomi Fakultas Ekonomi Universitas Udayana.

Daryanti, Ningsih dan Idah Zuhroh. 2010. Analisis Permintaan Kredit Investasi pada Bank Swasta Nasional di Jawa Timur. Jurnal Ekonomi Pembangunan Fakultas Ekonomi Universitas Muhammadiyah Malang.

Dendawijaya, Lukman. 2000. Manajemen Perbankan. Jakarta: Ghallia Indonesia.

Fifit, Syaiful. 2013. Pengaruh Risiko Kredit dan Tingkat Kecukupan Modal Terhadap Tingkat Profitabilitas pada Perusahaan Perbankan yang Terdaftar di Bursa Efek Indonesia. Jurnal Akuntansi Fakultas Ekonomi Universitas Negeri Padang.

Hakim, Aditya Rahman. 2009. Pengaruh Pertumbuhan Dana Pihak Ketiga dan Aktiva Produktif Terhadap Net Interest Margin pada Bank Pemerintah. Skripsi Sekolah Tinggi Ilmu Ekonomi Perbanas Surabaya.

Hasibuan, S.P Malayu. 2004. Dasar-Dasar Perbankan. Jakarta: Bumi Aksara

Horne, James C. Van and John M. Machowicz. 2009. Prinsip-Prinsip Manajemen Keuangan. Jakarta: Salemba Empat. 
Khizer Ali, Muhammad Farhan Akhtar dan Prof. Hafiz Zafar Ahmed. 2011. BankSpesific and Macroeconomic Indicator of Profitability-Empirical Evidece from the Commercial Banks of Pakistan. International Journal of Business abd Social Science, 2 (6), pp: 235-242.

Mardi, dan Faradila, L. 2016. Pengaruh Non Performing Loan (NPL) dan Bunga Pinjaman terhadap Tingkat Profitabilitas Bank Umum Swasta Nasional. Jurnal Organisasi dan Manajemen. 12 (1), pp:79-88..

Munawir, Slamet. 2002. Analisis Informasi Keuangan. Yogyakarta: Liberty.

Nurdin, Maryam., Indira Pasiangi. 2010. Implikasi Kolektabilitas Kredit Terhadap Profitabilitas PT. Bank Rakyat Indonesia (Persero) Tbk. Progresif. 3 (2), hal. 185-198

Pradnyani, Diah Ayu. 2011. Pengaruh Profesionalisme Badan Pengawas, kinerja Keuangan, dan Pengungkapan Sukarela Pada Tingkat Kepercayaan Nasabah Lembaga Perkreditan Desa di Kota Denpasar. Skripsi Sarjana Jurusan Akuntansi Fakultas Ekonomi Universitas Udayana. Denpasar.

Pradnyawati, I Gusti Agung Ayu. 2012. Pengaruh Pertumbuhan Aktiva Produktif, Dana Pihak Ketiga, Ukuran Perusahaan, dan Jumlah Nasabah pada Kinerja Operasioanal LPD di Kota Denpasar. Skripsi sarjana Ekonomi pada Program Ekstensi Fakultas Ekonomi Universitas Udayana, Denpasar.

Rastyniyati, I.G.K.A Ulupui. 2015. Pengaruh Pertumbuhan Kredit Pada Profitabilitas dengan Tingkat Perputaran Kredit Sebagai Variabel Pemoderasi. Skripsi Akuntansi Fakultas Ekonomi Universitas Udayana.

Rusydi, Muhammad dan Fakhri, Hafid. 2007. Pengaruh Penyaluran Kredit Terhadap Profitabilitas Pada PT. Bank XYZ cabang Pangkep. Jurnal Ekonomi Balance Fekom Unismuh Makassar, h: 37-65.

Saputra Eka. 2014. Pengaruh Pertumbuhan Dana Pihak Ketiga (DPK), Penyaluran Kredit, dan Kredit bermasalah terhadap Profitabilitas pada Lembaga Perkreditan Desa (LPD) Kecamatan Karangasem. E-Journal Bisma Universitas Pendidikan Ganesha, 2. 
ISSN: 2302-8556

E-Jurnal Akuntansi Universitas Udayana

Vol.24.1.Juli (2018): 399-421

Sastrawan, Putra. 2014. Pengaruh Pertumbuhan Tabungan dan Kredit terhadap Profitabilitas pada Lembaga Perkreditan Desa (LPD). E-Journal Bisma Universitas pendidikan Ganesha, (2).

Suartana, I Wayan. 2013. Risk Based audit Berbasis Budaya pada Lembaga Perkreditan Desa (LPD) Menuju Inklusi keuangan Berkelanjutan. Denpasar: Udayana Universitas Press.

Sudirman. 2000. Manajemen Perbankan. Edisi Pertama. Denpasar: PT BP.

Sugiyono. 2012. Metode Penelitian Bisnis. Bandung: CV.Alfabeta. 